\title{
ANALISIS ATAS PENGHINDARAN PAJAK (TAX AVOIDANCE) PADA PERUSAHAAN PROPERTI DAN REAL ESTATE DI INDONESIA
}

\author{
Yanuar Irawan*1, Havid Sularso ${ }^{2}$, Yusriati Nur Farida ${ }^{3}$. \\ ${ }^{1}$ Sekretariat Komite Pengawas Perpajakan, Kementerian Keuangan Republik Indonesia \\ 2,3 Jurusan Akuntansi, Fakultas Ekonomi dan Bisnis, Universitas Jenderal Soedirman, \\ Jl. HR. Boenyamin No. 708, Purwokerto 531222, Jawa Tengah, Indonesia \\ *Email Corresponding : wan.yanuar@gmail.com
}

\begin{abstract}
Abtraksi
Penelitian ini bertujuan untuk menguji pengaruh ukuran perusahaan (SIZE), profitabilitas (ROA), leverage (DAR), kepemilikan institusional (INST) dan kualitas audit (QA) terhadap penghindaran pajak. Objek penelitian ini adalah perusahaan properti dan real estate yang terdaftar dalam bursa efek Indonesia pada tahun 2013 - 2015. Penelitian ini menggunakan teknik sampling nonprobability sampling dengan teknik purposive sampling dengan level signifikansi 5\%. Data dianalisis menggunakan metode regresi panel dan diproses menggunakan Ms. Excel dan program Eviews version 9. Pengujian statistik menunjukan bahwa secara simultan SIZE, ROA, DAR, INST, dan QA berpengaruh secara signifikan terhadap penghindaran pajak. ROA merupakan variabel yang paling berpengaruh terhadap penghindaran pajak. Secara parsial, SIZE dan ROA berpengaruh positif signifikan terhadap penghindaran pajak. QA secara parsial memiliki pengaruh negatif signifikan terhadap penghindaran pajak. Sementara DAR dan INST tidak memiliki penghindaran pajak. Hasil penelitian mengindikasikan bahwa semua variabel independen dapat menjelaskan variansi variabel dependen sebesar 44,72\% berdasarkan pengujian koefisien determinasi (R2).
\end{abstract}

Kata Kunci : Ukuran perusahaan, Profiotabilitas, Leverage, Kepemilikan Institusional, Kualitas Audit, Penghindaran Pajak, Data Panel, Eviews

\begin{abstract}
The Research aims to examine the effect of Size of the Company (SIZE), Profitability (ROA), Leverage (DAR), Institutional Ownership (INST), and Quality of Audit (QA) to Tax Avoidance. The object under study is property and real estate companies that listed on the Indonesia Stock Exchange for the years 2013-2015. The sampling method used in this study is nonprobability sampling with purposive sampling technique and the level of significance is $5 \%$. Data were analyzed using panel data regression methods and processed with Ms. Excel and EViews version 9 program. Statistical test showed that simultaneously SIZE, ROA, DAR, INST, and QA have significant effect on tax avoidance. ROA is the most dominant variable affect tax avoidance. Partially, SIZE and ROA has significant positively effect on tax avoidance. QA partially has significant negatively effect on tax avoidance. Meanwhile, DAR and INST showed no effect on tax avoidance. The results of this study indicate that, all independent variables can explain the variance in the dependent variable $44,72 \%$ based on determination coefficient test (R2).
\end{abstract}

Key words : Size of the Company, Profitability, Leverage, Institutional Ownership, Quality of Audit, Tax Avoidance, Panel Data, Eviews. 


\section{PENDAHULUAN}

Pajak mempunyai peranan yang sangat penting dalam kehidupan bernegara, khususnya di dalam pelaksanaan pembangunan karena pajak merupakan sumber pendapatan negara untuk membiayai semua pengeluaran termasuk pengeluaran pembangunan. Pajak merupakan sumber utama penerimaan negara. Tanpa pajak, sebagian besar kegiatan negara sulit untuk dapat dilaksanakan. Penggunaan uang pajak meliputi mulai dari belanja pegawai sampai dengan pembiayaan berbagai proyek pembangunan.

Peran penerimaan pajak bagi suatu negara menjadi sangat dominan dalam menunjang jalannya roda pemerintahan dan pembiayaan pembangunan. Disamping fungsi budgetair (fungsi penerimaan), pajak juga melaksanakan fungsi redistribusi pendapatan dari masyarakat yang mempunyai kemampuan ekonomi yang lebih tinggi kepada masyarakat yang kemampuannya lebih rendah. Oleh karena itu, tingkat kepatuhan wajib pajak dalam melaksanakan kewajiban perpajakannya secara baik dan benar merupakan syarat mutlak untuk tercapainya fungsi redistribusi pendapatan.

Upaya optimalisasi penerimaan pajak dilakukan oleh pemerintah dalam hal ini Direktorat Jenderal Pajak (DJP) melalui kegiatan intensifikasi dan perluasan basis pajak melalui kegiatan ekstensifikasi. Dari kegiatan extra effort ekstensifikasi, DJP berhasil merealisasikan penerimaan pajak sebesar Rp 24,93 triliun. Jumlah wajib pajak terdaftar di tahun 2015 mengalami peningkatan menjadi 33.336.122 atau meningkat sebesar 9,03 persen dibanding tahun sebelumnya (DJP, 2016). Namun demikian usaha untuk mengoptimalkan penerimaan sektor ini bukan tanpa kendala. Salah satu kendala dalam rangka optimalisasi penerimaan pajak adalah adanya penghindaran pajak (tax avoidance) (Agusti, 2014). Laporan tahunan DJP tahun 2015 menunjukkan tingkat kepatuhan wajib pajak yang masih rendah yakni sebesar $60,42 \%$ dan penurunan dari target penerimaan yakni sebesar 9,91\% (DJP, 2016). Rendahnya kepatuhan wajib pajak dan penurunan penerimaan pajak ini menandakan terdapat upaya yang dilakukan perusahaan dalam rangka meminimalisasi beban pajak yang harus dibayar.

Pemungutan pajak bukan merupakan hal yang mudah untuk diterapkan. Pajak dari sisi perusahaan merupakan salah satu faktor yang dipertimbangkan karena pajak dianggap beban yang dapat mempengaruhi kelangsungan hidup perusahaan (Masri dan Martani, 2012). Dari sisi fiskus, pajak merupakan salah satu sumber pendapatan yang secara potensial dapat mempengaruhi dan meningkatkan penerimaan negara. Kedua sisi tersebut menyebabkan adanya perbedaan kepentingan antara fiskus dengan perusahaan dimana fiskus sebagai prinsipal (pemangku kepentingan) menginginkan penerimaan pajak yang sebesar-besarnya dari masyarakat, sedangkan perusahaan sebagai agent menginginkan pembayaran pajak yang seminimal mungkin kepada negara (Hardika, 2007). 
Perbedaan kepentingan antara fiskus dan perusahaan berdasarkan teori keagenan akan menimbulkan ketidakpatuhan yang dilakukan oleh wajib pajak atau pihak manajemen perusahaan yang akan berdampak pada upaya perusahaan untuk melakukan penghindaran pajak. Strategi penghindaran pajak (tax avoidance) merupakan cara yang diperkenankan undang-undang namun strategi yang diterapkan perusahaan ini tetap merugikan penerimaan negara (Shophar dalam Agusti, 2014). Sebagaimana informasi yang disampaikan Bappenas (2005), terkait dengan penghindaran pajak ini di Indonesia pada tahun 2005 terdapat 750 perusahaan penanaman modal asing yang ditengarai melakukan penghindaran pajak dengan melaporkan rugi dalam 5 tahun berturut-turut dan tidak membayar pajak. Fenomena penghindaran pajak lainnya yang terjadi di Indonesia sebagaimana ditulis oleh Suryana (2013) dalam artikel ilmiah perpajakan yakni di tahun 2013 tepatnya di Kota Semarang diketahui terdapat upaya penghindaran pajak yang dilakukan pengembang (developer) yakni penjualan rumah mewah seharga Rp 7,1 milyar, namun di akta notaris hanya tertulis Rp 940 juta. Atas selisih nilai transaksi sebesar $\mathrm{Rp}$ 6,1 milyar tersebut diperkirakan terdapat potensi penghindaran pajak sebesar Rp 900 juta.

Penelitian yang dilakukan oleh Makhfatih (2005) menyatakan bahwa faktor penyebab praktik penghindaran pajak maupun penggelapan pajak meliputi faktor internal dan faktor eksternal. Ukuran perusahaan mencerminkan seberapa besar sumber daya yang dimiliki perusahaan, sehingga ukuran perusahaan dianggap mampu mempengaruhi cara sebuah perusahaan dalam memenuhi kewajiban pajaknya dan merupakan faktor yang dapat menyebabkan terjadinya tax avoidance. Penelitian mengenai pengaruh ukuran perusahaan terhadap penghindaran pajak telah dilakukan oleh beberapa pihak namun dari beberapa penelitian tersebut terdapat beberapa perbedaan kesimpulan. Asfiyati (2012), Kristiana (2013), dan Rusydi (2013) menyimpulkan bahwa ukuran perusahaan tidak berpengaruh terhadap penghindaran pajak. Di lain pihak, penelitian yang dilakukan Nugroho (2011), Adelina (2012), Fatharani (2012), Darmawan (2014), Marfu'ah (2015), dan Dewinta (2016) menunjukkan hubungan positif antara ukuran perusahaan dengan penghindaran pajak.

Faktor berikutnya adalah profitabilitas. Tingkat profitabilitas perusahaan menunjukkan kemampuan perusahaan dalam memperoleh laba. Perusahaan yang memiliki total aset yang besar cenderung lebih mampu dan stabil untuk menghasilkan laba jika dibandingkan dengan perusahaan dengan total aset yang kecil (Indriani, 2005 dalam Dewinta, 2016). Laba yang besar dan stabil akan cenderung mendorong perusahaan untuk melakukan praktik penghindaran pajak (tax avoidance). Profitabilitas terdiri dari beberapa rasio, salah satunya adalah Return On Assets (ROA). ROA berfungsi untuk mengukur efektivitas perusahaan dalam penggunaan sumber daya yang dimilikinya (Siahan, 2004). Penelitian yang dilakukan oleh Kurniasih dan Maria (2013), dan Agusti (2014) menunjukkan bahwa tingkat profitabilitas perusahaan memiliki 
pengaruh negatif signifikan terhadap penghindaran pajak. Namun demikian, penelitian yang dilakukan oleh Nugroho (2011), Fatharani (2012), dan Darmawan (2014) menunjukkan bahwa profitabilitas berpengaruh positif terhadap penghindaran pajak perusahaan.

Leverage merupakan tingkat utang yang digunakan perusahaan dalam melakukan pembiayaan. Perusahaan menggunakan leverage dengan tujuan agar keuntungan yang diperoleh lebih besar daripada biaya atas aset dan sumber dananya dengan demikian dapat meningkatkan keuntungan pemegang saham. Selain itu, leverage yang tinggi dalam suatu perusahaan akan mengurangi beban pajak yang ditanggung oleh perusahaan, sehingga langkah utang lebih dipilih oleh manajemen sebagai upaya menghindari beban pajak yang lebih besar. Penelitian sebelumnya tentang pengaruh leverage terhadap penghindaran pajak dilakukan oleh Noor (2010) yang menjelaskan bahwa perusahaan dengan jumlah utang lebih banyak memiliki tarif pajak yang efektif baik, hal ini berarti bahwa dengan jumlah utang yang banyak, upaya perusahaan untuk melakukan tax avoidance akan cenderung lebih kecil. Penelitian lain dari Kurniasih dan Maria (2013) dan Darmawan (2014) menunjukkan bahwa leverage tidak berpengaruh signifikan terhadap tax avoidance.

Penghindaran pajak juga dimungkinkan terjadi dikarenakan faktor tata kelola perusahaan. Beberapa faktor diantaranya adalah kepemilikan institusional dan kualitas audit. Kepemilikan institusional menunjukkan besarnya persentase kepemilikan saham yang dimiliki oleh investor dalam bentuk badan usaha atau institusi. Adanya pemilik saham institusi memiliki pengaruh secara langsung kepada perusahaan khususnya dalam hal tata kelola peerusahaan (corporate governance). Investor institusi pada umumnya bersifat kooperatif dengan peraturan yang berlaku mengingat apabila terjadi permasalahan maka nama baik institusi pemegang saham dapat terseret dalam permasalahan tersebut. Penelitian sebelumnya yang dilakukan oleh Ngadiman dan Puspitasari (2014) dan Maraya dan Yendrawati (2016) menyimpulkan bahwa kepemilikan institusional memiliki pengaruh signifikan negatif terhadap penghindaran pajak. Sebaliknya, penelitian yang dilakukan oleh Annisa dan Kurniasih (2012), Hanum dan Zulaikha (2013) serta Dewi dan Jati (2014) menyimpulkan bahwa kepemilikan institusional tidak berpengaruh signifikan terhadap penghindaran pajak

Transparansi merupakan faktor utama dalam pelaksanaan tata kelola perusahaan yang baik. Transparansi mensyaratkan adanya pengungkapan yang akurat. Salah satu bentuk monitoring yang dapat menurunkan biaya agensi adalah audit (Jensen dan Meckling, 1976 dalam Anisa, 2011). Kualitas audit yang baik dapat tercermin dari pihak yang melakukan audit atau reviu atas laporan keuangan perusahaan. Semakin baik kualitas audit perusahaan maka upaya untuk melakukan penghindaran pajak akan semakin rendah mengingat adanya pihak ketiga yang secara rutin (tahunan) melakukan audit khususnya terkait kepatuhan akan peraturan yang berlaku. Penelitian sebelumnya mengenai pengaruh kualitas audit terhadap 
penghindaran pajak dilakukan oleh beberapa orang, diantaranya Anisa (2011) dan Maraya dan Yendrawati (2016) yang menyimpulkan kualitas audit berpengaruh signifikan terhadap penghindaran pajak. Sementara itu, penelitian yang dilakukan oleh Hamed dan Boussaidi (2015) menyimpulkan kualitas audit tidak berpengaruh terhadap penghindaran pajak.

Mempertimbangkan fenomena yang terjadi dan perbedaan hasil penelitian sebelumnya tentang penghindaran pajak, penelitian ini bermaksud untuk menganalisis lebih lanjut mengenai faktor yang berpengaruh terhadap penghindaran pajak. Faktor-faktor tersebut diantaranya ukuran perusahaan, profitabilitas, leverage, kepemilikan institusional dan kualitas audit. Selain itu, dalam pelaksanaan penelitian ini populasi yang digunakan adalah perusahaan terdaftar di Bursa Efek Indonesia yang bergerak di sektor properti dan real estate. Hal ini berbeda dengan penelitian-penelitian sebelumnya yang dilakukan pada perusahaan manufaktur dikarenakan fenomena penghindaran pajak juga banyak terjadi pada sektor properti.

Berdasarkan hal tersebut diatas, penelitian akan menganalisis mengenai pengaruh ukuran perusahaan, profitabilitas, leverage, kepemilikan institusional dan kualitas audit terhadap penghindaran pajak dengan studi pada perusahaan terdaftar di Bursa Efek Indonesia Tahun 2013 sampai dengan 2015.

Tujuan yang ingin dicapai dari penelitian yang dilakukan adalah menguji pengaruh secara simultan ukuran perusahaan, profitabilitas, leverage, kepemilikan institusional, dan kualitas audit terhadap penghindaran pajak dan menguji variabel yang paling berpengaruh terhadap penghindaran pajak.

\section{TINJAUAN PUSTAKA DAN PERUMUSAN HIPOTESIS TINJAUAN PUSTAKA}

\section{Teori Agensi}

Teori Agensi (Agency Theory) Jensen dan Meckling, 1976 (dalam Hakim, 2015) teori agensi menyatakan bahwa antara manajemen dan pemilik mempunyai kepentingan yang berbeda. Perusahaan yang memisahkan fungsi pengelolaan dan kepemilikan akan rentan terhadap konflik keagenan Lambert, 2001 (dalam Hakim, 2015). Model keagenan merancang sebuah sistem yang melibatkan kedua belah pihak, sehingga diperlukan kontrak kerja antara pemilik (principal) dan manajemen (agent). Kesepakatan tersebut diharapkan dapat memaksimumkan untilitas principal dan dapat menjamin agen untuk menerima reward dari hasil aktivitas pengelolaan perusahaan. Perbedaan kepentingan antara pemilik dan manajemen terletak pada memaksimalkan manfaat (utility) pemilik (principal) dengan kendala (constraint) manfaat (utility) dan insentif yang akan diterima oleh manajemen (agent). Kepentingan yang berbeda sering menyebabkan konflik kepentingan antara pemegang saham/pemilik (principal) dengan manajemen (agent). 
Teori agensi merupakan model yang digunakan untuk memformulasikan permasalahan antara manajemen (agent) dengan pemilik (principal). Kinerja perusahaan telah dicapai oleh pihak menajemen telah diinformasikan kepada pihak pemilik (principal) dalam bentuk laporan keuangan. Sistem desentralisasi, manajemen mempunyai informasi yang superior dibandingkan dengan pemilik, karena manajemen telah menerima pendelegasian untuk pengambilan keputusan/kebijakan perusahaan. Manajemen dapat menentukan kebijakan yang mengarah kepada peningkatan level kompensasinya secara potensial ketika pemilik tidak dapat memonitoring secara sempurna aktivitas manejemen. Seluruh tindakan telah didelegasikan oleh pemilik (principal) kepada manajer (agent) pada model principal agent.

\section{Penghindaran Pajak (Tax Avoidance)}

Pemerintah melalui Direktorat Jenderal Pajak (DJP) selalu berusaha untuk memperbaharui peraturan-peraturan perpajakan untuk meningkatkan penerimaan pajak.

Akan tetapi, di sisi lain perusahaan juga selalu berusaha untuk menghemat pembayaran pajaknya yang dapat dilakukan dengan cara yang legal yakni penghindaran pajak (tax avoidance) atau secara ilegal dengan penggelapan pajak (tax evasion). Asumsi pajak sebagai biaya akan mempengaruhi laba (profit margin), sedangkan asumsi pajak sebagai distribusi laba akan mempengaruhi tingkat pengembalian atas investasi (rate of return on investment). Secara ekonomis pajak merupakan unsur pengurang laba yang tersedia untuk dibagi atau diinvestasikan kembali oleh perusahaan, Suandy, 2011:8 (dalam Utami, 2013). Suandy, 2011:18 (dalam Utami, 2013) mendefinisikan peghindaran pajak sebagai rekayasa 'tax affairs' yang masih tetap dalam bingkai ketentuan perpajakan (lawful). Menurut Heber (dalam Mulyani et al, 2013) pengertian tax avoidance adalah upaya Wajib Pajak dalam memanfaatkan peluangpeluang (loopholes) yang ada dalam Undang-Undang perpajakan, sehingga dapat membayar pajak lebih rendah. Suandy (2011), umumnya Wajib Pajak berusaha untuk membayar pajak sekecil mungkin, karena dengan membayar pajak berarti mengurangi kemampuan ekonomis Wajib Pajak. Berdasarkan pengertian yang dijelaskan oleh para ahli dapat ditarik kesimpulan bahwa penghindaran pajak (tax avoidance) merupakan legal utilization atau legal arrangements of tax fair's affairs yaitu suatu perbuatan legal dengan memanfaatkan celah dari UndangUndang Perpajakan untuk meminimalkan beban pajak penghasilan yang seharusnya dibayar.

\section{PERUMUSAN HIPOTESIS}

Pengaruh Ukuran Perusahaan, Profitabilitas, Leverage, Kepemilikan Institusional, dan Kualitas Audit terhadap Penghindaran Pajak

Ukuran perusahaan, profitabilitas, dan leverage merupakan variabel independen dari sisi keuangan perusahaan. Ketiga variabel digunakan sebagai alat pengukur seberapa besar aset yang dimiliki serta seberapa besar laba yang diperoleh dan biaya yang dikeluarkan 
Analisis Atas Penghindara Pajak (TAX AVOIDANCE) ...

untuk mendapatkan aset tersebut. Variabel independen lainnya adalah kepemilikan institusional dan kualitas audit yang mencerminkan pelaksanaan corporate governance suatu entitas bisnis. Kepemilikan institusional menunjukkan keterlibatan investor institusi dalam pegambilan kebijakan perusahaan. Kualitas audit menunjukkan pengaruh pemeriksaan laporan keuangan yang dilakukan oleh Kantor Akuntan Publik (KAP) dengan reputasi terbaik terhadap praktik yang dilakukan manajemen perusahaan.

Pada penelitian yang dilakukan oleh Annisa (2011), Kurniasih dan Sari (2013), dan Marfu'ah (2015) menyatakan bahwa variabel independen atas penelitian mereka masing-masing, secara silmultan berpengaruh terhadap variabel dependen berupa penghindaran pajak.

H1 : Ukuran Perusahaan, Profitabilitas, Leverage, Kepemilikan Institusional dan Kualitas Audit secara simultan berpengaruh terhadap Penghindaran Pajak

Variabel paling berpengaruh terhadap Penghindaran Pajak

Menurut Kasmir (2008), "Rasio profitabilitas merupakan rasio untuk menilai kemampuan perusahaan dalam mencari keuntungan (laba)". Laba merupakan salah satu ukuran penilaian efektivitas kinerja manajemen kepada pemilik saham. Menurut Statement of Financial Accounting Concept (SFAC) No. 8, informasi laba merupakan perhatian utama untuk menaksir kinerja atau pertanggungjawaban manajemen. Selain itu informasi laba juga membantu pemilik atau pihak lain dalam menaksir earnings power perusahaan di masa yang akan datang. Adanya kecenderungan lebih memperhatikan laba ini disadari oleh manajemen, khususnya manajer yang kinerjanya diukur berdasarkan informasi laba tersebut. Hal ini mendorong timbulnya perilaku menyimpang, salah satu tindakan yang tidak terhindarkan adalah praktik penghindaran pajak. Penghindaran pajak dilakukan mengingat praktik ini secara langsung berpengaruh pada laba. Sebagaimana diketahui, unsur dalam perhitungan laba dalam laporan laba rugi perusahaan adalah pendapatan dan beban, sehingga selain meningkatkan pendapatan langkah yang dilakukan adalah dengan meminimalisasi beban perusahaan.

Penelitian terdahulu yang dilakukan oleh Darmawan (2014), Agusti (2014), Dewinta (2015), dan Ifanda (2016) menunjukkan bahwa variabel profitabilitas menjadi variabel paling berpengaruh terhadap penghindaran pajak. Hal ini nampak dari koefisien model regresi berganda yang dihasilkan dari perhitungan uji simultan.

Berdasarkan dasar teori sebagaimana diuraikan di atas dan hasil penelitian terdahulu maka hipotesis penelitian ini adalah

H2 : Variabel Profitabilitas paling berpengaruh terhadap Penghindaran Pajak 


\section{METODE PENELITIAN}

Jenis penelitian yang akan digunakan adalah penelitian eksplanatori (Explanatory Research) dengan pendekatan kuantitatif. Menurut Sugiyono (2010) penelitian eksplanatori adalah penelitian yang menjelaskan hubungan kausal antara variabel-variabel yang mempengaruhi hipotesis.

Populasi dalam penelitian ini adalah seluruh perusahaan yang bergerak pada sektor properti dan real estate yang terdaftar (listing) di Bursa Efek Indonesia. Sebagaimana penelitian yang pernah dilakukan Marfu'ah (2015), metode pemilihan sampel yang digunakan adalah nonprobability sampling dengan teknik purposive sampling dengan kriteria :

1. Perusahaan dengan data laporan keuangan yang lengkap (2013 s.d. 2015);

2. Perusahaan dengan nilai laba positif.

Berdasarkan kriteria tersebut maka jumlah sampel yang digunakan dalam penelitian adalah sebanyak 32 perusahaan selama tiga tahun.

Penelitian ini menggunakan uji asumsi klasik untuk menguji apakah dalam sebuah model regresi, variabel independen, variabel dependen, atau keduanya mempunyai distribusi normal atau tidak, tidak terjadi autokorelasi, tidak terjadi heterokedastisitas, dan tidak mengandung multikolinearitas. Uji asumsi klasik ini terdiri dari empat macam pengujian, yaitu uji normalitas, uji multikolinearitas, uji heterokedastisitas dan uji autokorelasi. Uji normalitas bertujuan untuk menguji apakah dalam model regresi, variabel pengganggu, atau residual memiliki distribusi normal. Pada penelitian ini digunakan statistik yang dikembangkan Jarque-Bera untuk menguji normalitas data yang digunakan.

Uji multikolinearitas bertujuan untuk mengetahui apakah dalam model regresi ditemukan adanya korelasi antar variabel bebas atau tidak, model yang baik seharusnya tidak terjadi korelasi yang tinggi diantara variabel bebas (Ghozali, 2011). Untuk mengetahui ada tidaknya multikolinearitas dalam suatu model regresi, dapat dilakukan dengan melihat nilai tolerance dan nilai Variance Inflation Factor (VIF). Jika nilai VIF lebih besar dari 10 dan nilai tolerance kurang dari 0,9 maka terjadi multikolinearitas.

Uji heterokedastisitas bertujuan untuk menguji apakah dalam model regresi terjadi ketidaksamaan varian dari residual satu pengamatan ke pengamatan yang lain. Jika varian dari residual satu pengamatan ke pengamatan lain tetap, maka disebut homokedastisitas dan jika berbeda disebut heterokedastisitas. Metode pengujian heterokedastisitas menggunakan Uji Glejser dengan melihat probabilitas signifikasinya. Jika nilai signifikasinya di atas tingkat kepercayaan 5\% maka dapat disimpulkan tidak mengandung adanya heterokedastisitas (Ghozali, 2009).

Uji autokorelasi merupakan pengujian asumsi dalam regresi dimana variabel dependen tidak berkorelasi dengan dirinya sendiri. Uji autokorelasi yang digunakan dalam penelitian ini 
Analisis Atas Penghindara Pajak (TAX AVOIDANCE) ...

adalah uji Durbin Watson (DW test). Suatu penelitian dikatakan tidak terjadi autokorelasi apabila $\mathrm{du}<\mathrm{d}<4$-du.

Teknik analisis yang digunakan yaitu dengan menggunakan model analisis regresi data panel.Data panel adalah gabungan antara data cross section dan data time series, dimana unit cross section yang sama diukur pada waktu yang berbeda. Analisis statistik dengan regresi data panel dalam penelitian ini akan dilakukan dengan bantuan perangkat lunak Microsoft Excel dan Eviews versi 9.

\section{HASIL DAN PEMBAHASAN}

\section{Pengujian Asumsi Klasik}

Hasil pengujian asumsi klasik dan analisis data terhadap variabel yang diteliti adalah sebagai berikut:

Uji Normalitas

Nilai signifikansi residual hasil regresi antara variabel dependen dengan variabel independennya adalah sebesar 0,202001 lebih besar dari taraf signifikansi sebesar 0,05. Selain itu, nilai Jarque-Bera sebesar 3,1989 lebih kecil dari nilai Chi Square $(\chi 2)$ sebesar 150,98943 sehingga disimpulkan residual dalam penelitian ini berdistribusi normal.

Uji Multikolinearitas

Hasil penelitian berdasarkan nilai VIF (Variance Inflation Factor) tidak menunjukkan adanya hubungan linier antar variabel independen. Hal ini nampak dari nilai korelasi antar variabel yang kurang dari 0,90. Nilai korelasi terbesar sebesar 0,600338 yakni korelasi antara variabel CETR dengan ROA.

Uji Heterokedastisitas

Berdasarkan hasil Uji Glejser memperlihatkan bahwa variabel independen yaitu ukuran perusahaan, profitabilitas, leverage, kepemilikan institusional dan kualitas audit, berturutturut mempunyai nilai signifikansi sebesar 0,499,0,939, 0,102, 0,600, 0, 665. Hasil uji tersebut memperlihatkan nilai probabilitas setiap variabel diatas nilai 0,05. Hal ini menunjukkan bahwa dalam model regresi penelitian tidak terdapat unsur heterokedastisitas.

Uji Autokorelasi

Dari hasil regresi diperoleh nilai Durbin Watson statistik sebesar 2,044825. Dengan nilai DW Tabel $\mathrm{n}=96$ dan $\mathrm{k}=5$ pada $\alpha=5 \%$, maka didapat nilai $\mathrm{dL}=1,557$ dan $\mathrm{dU}=1,778$. Berdasarkan aturan pengambilan keputusan DW, nilai DW statistik berada du $<$ D-W stat $<$ 4 -du $(1,778<2,044825<2$,222) sehingga dapat disimpulkan bahwa tidak terdapat masalah autokorelasi pada model regresi dalam penelitian ini. 
Berdasarkan hasil uji Langrange Multiplier dihasilkan nilai probabilitas Breusch Pagan sebesar 0,5354 lebih besar dari nilai kritis $(\alpha)$ sebesar 0,05, sehingga dapat disimpulkan Common Effect Model (CEM) lebih tepat digunakan dibandingkan dengan Random Effect Model (REM).

Hasil uji koefisien determinasi menunjukkan nilai $\mathrm{R}^{2}$ sebesar 0,447208 atau 44,7208\%. Hal tersebut berarti variabel ukuran perusahaan, profitabilitas, leverage, kepemilikan institusional, dan kualitas audit mampu menjelaskan variabel dependen yaitu penghindaran pajak sebesar $44,7208 \%$, sedangkan sisanya yaitu 55,2792\% dijelaskan oleh variabel lain di luar penelitian ini.

\section{Pengujian Hipotesis}

H1 : Ukuran Perusahaan, Profitabilitas, Leverage, Kepemilikan Institusional dan Kualitas Audit secara simultan berpengaruh terhadap Penghindaran Pajak

Berdasarkan hasil uji regresi CEM menunjukkan bahwa nilai F-hitung sebesar 14,562 dengan probabilitas signifikansi sebesar 0,000. Oleh karena nilai F-hitung $(14,562)>$ F-tabel $(2,32)$ dan nilai signifikansi 0,000 < 0,05, maka Ho ditolak dan Ha diterima.

Dengan demikian hipotesis pertama (H1) yang menyatakan bahwa varibel bebas, yakni ukuran perusahaan, profitabilitas, leverage, kepemilikan institusional, dan kualitas audit secara silmultan mempunyai pengaruh terhadap variabel terikat yakni penghindaran pajak, diterima.

H2 : Variabel Profitabilitas paling berpengaruh terhadap Penghindaran Pajak Hasil uji elastisitas menunjukkan bahwa variabel profitabilitas (ROA) memiliki nilai paling besar yakni sebesar 0,212471. Hal ini menunjukkan bahwa variabel profitabilitas merupakan variabel paling berpengaruh terhadap penghindaran pajak dibandingkan dengan variabel lain (ukuran perusahaan, leverage, kepemilikan institusional dan kualitas audit). Dengan demikian, hasil tersebut secara jelas menerima hipotesis kedua yakni variabel profitabilitas paling berpengaruh terhadap penghindaran pajak.

Teori agensi akan memacu para manajemen (agent) untuk meningkatkan laba perusahaan. Agent dalam teori agensi akan berusaha mengelola beban pajaknya agar tidak mengurangi kompensasi kinerja agent sebagai akibat dari berkurangnya laba perusahaan oleh beban pajak. Perusahaan yang mampu mengelola sumber daya dengan baik akan memperoleh keuntungan dari insentif pajak dan kelonggaran pajak lainnya sehingga perusahaan tersebut akan terlihat untuk melakukan penghindaran pajak (Dewinta, 2015).

\section{KESIMPULAN}

\section{Kesimpulan}

Berdasarkan hasil penelitian yang telah dilakukan dan didukung oleh teori dan penelitian terdahulu, maka diperoleh kesimpulan bahwa Ukuran Perusahaan, Profitabilitas, Leverage, Kepemilikan Institusional, Dan Kualitas Audit secara simultan berpengaruh terhadap 
Analisis Atas Penghindara Pajak (TAX AVOIDANCE) ...

Penghindaran Pajak. Dan profitabilitas merupakan variabel paling berpengaruh terhadap Penghindaran Pajak.

\section{Implikasi}

Berdasarkan kesimpulan penelitian ini, terdapat implikasi terkait pengaruh variabel ukuran perusahaan, profitabilitas, leverage, kepemilikan institusional, dan kualitas audit terhadap penghindaran pajak yaitu pajak merupakan sumber penerimaan terbesar negara dan sangat penting dalam mendukung program pembangunan nasional. Untuk itu, faktor-faktor yang berpengaruh terhadap praktik penghindaran pajak kiranya mendapat perhatian pemerintah dalam hal ini fiskus dalam proses pemungutan pajak. Selain itu, hendaknya pemerintah memperhatikan informasi profitabilitas perusahaan dalam melaporkan pajak dengan seksama, sehingga diharapkan penghindaran pajak dapat diminimalisir

\section{Keterbatasan}

Selanjutnya, penelitian ini memiliki keterbatasan yaitu informasi yang dibutuhkan dalam laporan keuangan perusahaan audited salah satunya adalah beban pajak. Pada tahun 2015, terjadi perubahan struktur dalam laporan laba rugi perusahaan dimana beban pajak yang bersifat final letaknya tidak di bagian beban pajak sebagai pengurang laba sebelum pajak dan bunga (EBIT) tetapi dimasukkan dalam beban operasional perusahaan. Hal ini menyebabkan laba sebelum pajak sebagaimana tercantum masih harus ditambahkan dengan beban pajak final tersebut untuk mendapatkan laba sebelum pajak sesungguhnya. Selain itu, pada beberapa perusahaan terjadi perubahan (revisi) laporan keuangan tahunan. Hal ini perlu dicermati mengingat pada beberapa akun dalam laporan keuangan dimungkinkan terjadi perubahan khusunya informasi yang dibutuhkan dalam penelitian.

\section{Saran}

Berdasarkan keterbatasan tersebut maka saran untuk penelitian selanjutnya adalah hendaknya mencari informasi untuk data penelitian secara lebih lengkap, sehingga penelitian dapat dilakukan dengan mudah dan tepat. Kemudian, penelitian selanjutnya hendaknya mencermati informasi data yang dibutuhkan dalam penelitian termasuk apabila terjadi perubahan data selama penelitian berlangsung, agar hasil penelitian dapat lebih maksimal

\section{Daftar Pustaka}

Adelina, Theresa. 2012. Pengaruh Karakteristik Perusahaan dan Reformasi Perpajakan terhadap Penghindaran Pajak di Industri Mnufaktur yang Trdaftar di Bursa Efek Indonesia Tahun 2008-2010. Skripsi Fakultas Ekonomi Unversitas Indonesia. Depok. 
Agusti, Mirna Yola. 2014. Pengaruh Profitabilitas, Leverage, Dan Corporate governance Terhadap Tax avoidance. Artikel Ilmiah. Universitas Negeri Padang. Padang.

Annisa, N.A., L. Kurniasih. 2012. Pengaruh Corporate Governance terhadap Tax Avoidance. Dalam Jurnal Akuntansi dan Auditing, 8(2): h:123-136. Universitas Sebelas Maret. Surakarta.

Annisa, Nuralifmida Ayu. 2011. Pengaruh Corporate Governance dan Corporate Social Responsibility Disclosure Terhadap Tax avoidance. Skripsi. Universitas Sebelas Maret. Surakarta.

Asfiyati. 2012. Pengaruh Corporate Governance, Kepemilikan Keluarga, dan Karakteristik Perusahaan Terhadap Tax Avoidance. Skripsi Fakultas Ekonomi Universitas Sebelas Maret, Surakarta.

Bappenas. 2005. Tak Mungkin Lima Tahun Terus Merugi. Diakses pada 15 Januari 2017 dari http://finance.detik.com/read/2005/11/21/164657/483116/4/ngaku-rugi-750pma-tak-bayar-pajak-selama-5-tahun-lebih.

Darmawan, I. G. H., \& Sukartha, I. M. (2014). Pengaruh Penerapan Corporate Governance, Leverage, Return On Assets, dan Ukuran Perusahaan pada Penghindaran Pajak. E-Jurnal Akuntansi Universitas Udayana 9.1. Bali.

Dewi, Ni Nyoman Kristiana dan I Ketut Jati. (2014). Pengaruh KarakterEksekutif, Karakteristik Perusahaan, dan Dimensi Tata Kelola Perusahaanyang Baik pada Tax Avoidance di Bursa Efek Indonesia. ISSN: 2302-8556, E-Jurnal Akuntansi Universitas Udayana 6.2 (2014), 249-260.

Dewinta, I. A. R. dan Setiawan, P. E. (2016). Pengaruh Ukuran Perusahaan, Umur Perusahaan, Profitabilitas, Leverage, dan Pertumbuhan Penjualan Terhadap Tax Avoidance. E-Jurnal Akuntansi Universitas Udayana, Vol.14, (No. 3), hal 15841613

Direktorat Jenderal Pajak (DJP). 2016. Laporan Tahunan 2015. www.pajak.go.id. Diakses pada 15 Januari 2017.

Fatharani, Nazhaira. 2012. Pengaruh Karaketeristik Kepemilikan, Reformasi Perpajakan, dan Hubungan Politik Terhadap Tindakan Pajak Agresif. Skripsi Fakultas Ekonomi Program Studi Akuntansi Universitas Indonesia.

Ghozali, Imam. 2011. Aplikasi Analisis Multivariate Dengan Program IBM SPSS 19 (edisi kelima). Semarang: Universitas Diponegoro.

Hakim, A. R. 2015. Pengaruh Aktiva Pajak Tangguhan dan Beban Pajak Tangguhan Terhadap Manajemen Laba. Skripsi. Sekolah Tinggi Ilmu Ekonomi Indonesia. Surabaya.

Hanum, Hashemi Rodhian dan Zulaikha Zulaikha. 2013. Pengaruh Karakteristik Corporate Governance Terhadap Effective Tax Rate (Studi Empiris pada BUMN yang Terdaftar di BEI 2009-2011). Diponegoro Journal Accounting.2: 1-10.

Hamed, M.S., dan Boussaidi.A. 2015. The Impact of Governance Mechanisms on Tax Aggressiveness: Empirical Evidence From Tunisisan Context. Journal of Asian Business Strategy, Vol.5(1).

Hardika, Nyoman Sentosa. 2007. Perencanaan Pajak sebagai Strategi Penghematan Pajak. Jurnal Bisnis dan Kewirausahaan. Volume 3 No.2. 103-112. 
Ifanda, Bily Al. 2016. Pengaruh Profitabilitas, Leverage, Dan Kompensasi Rugi Fiskal Terhadap Penghindaran Pajak. Skripsi. Universitas Lampung.

Jensen, M and Mackling, W. 1976. Theory of The Firm: Managerial Behavior, Agency Cost, and Ownership Structure. Journal of Financial Economics 3: 305-306.

Kasmir. 2008. Analisis Laporan Keuangan, Jakarta : Rajawali Pers.

Keputusan Menteri BUMN No. Kep-117/M-MBU/2002 tentang Penerapan Praktik Good Corporate governance pada Badan Usaha Milik Negara.

Kristiana, Ni Nyoman. 2013. Pengaruh Karakter Eksekutif, Karakteristik Perusahaan, dan Dimensi Tata Kelola Perusahaan yang Baik Pada Tax Avoidance Di Bursa Efek Indonesia. E-Jurnal Akuntansi Universitas Udayana. 6.2 (2014) : 249-260.

Kurniasih, T., \& Sari, M. M. R. 2013. Pengaruh Return On Assets, Leverage, Corporate Governance, Ukuran Perusahaan dan Kompensasi Rugi Fiskal pada Tax Avoidance.18(1), 58-66.

Maraya, Amila Dyan dan Yendrawati, Reni. 2016. Pengaruh Corporate governance dan Corporate Social Responsibility Disclosure Terhadap Tax avoidance. Naskah Publikasi.

Marfu'ah, Laila. 2015. Pengaruh Return On Asset, Leverage, Ukuran Perusahaan Kompensasi Rugi Fiskal Dan Koneksi Politik Terhadap Tax avoidance. Naskah Publikasi. Universitas Muhammadiyah Surakarta.

Mulyani, S., Darminto, dan M.G. Endang. 2013. Pengaruh Karakteristik Perusahaan, Koneksi Politik dan Reformasi Perpajakan terhadap Penghindaran Pajak (studi pada perusahaan manufaktur yang terdaftar di bursa efek tahun 2008-2012). Jurnal perpajakan 2(1).

Ngadiman, dan Puspitasari, C. (2014). Pengaruh Leverage, Kepemilikan Institusional, dan Ukuran Perusahaan terhadap Penghindaran Pajak (Tax Avoidance) pada Perusahaan Sektor Manufakturyang Terdaftar di Bursa Efek Indonesia 2010-2012. Jurnal Akuntansi, Vol 18, No 3, Halaman 408421.

Noor, Md Rohaya et al. 2010.Corporate Tax Planning: A Study on Corporate Effective Tax Rates on Malaysian Listed Company. International Journal of Trade, Economics and Finance Vol. 1 No. 2.

Nugroho, Andri Adi. 2011. Pengaruh Hubungan Politik dan Reformasi Perpajakan terhadap Tarif Pajak Efektif.Dalam Skripsi Fakultas Ekonomi Universitas Indonesia.

Keputusan Kepala BAPEPAM No. 11/PM/1997 Perubahan Peraturan Nomor Ix.C.7 Tentang Pedoman Mengenai Bentuk Dan Isi Pernyataan Pendaftaran Dalam Rangka Penawaran Umum Oleh Perusahaan Menengah Atau Kecil.

Makhfatih, Akhmad. 2005. Penggelapan Pajak di Indonesia: Studi Pajak Hotel non Bintang. Disertasi Doktor Universitas Gadjah Mada, Yogyakarta.

Masri, Indah dan Martani, Dwi. 2012. Pengaruh Tax Avoidance terhadap Cost of Debt. Jurnal Magister Akuntasi. Fakultas Ekonomi Universitas Indonesia.

Republik Indonesia. 2008. Undang-Undang Nomor 20 Tahun 2008 Tentang Usaha Mikro, Kecil dan Menengah. Jakarta.

Republik Indonesia. 2009. Peraturan Menteri Perdagangan Nomor 46/M-Dag/Per/9/2009. Jakarta 
Rusydi. M. Khoiru. 2013. Pengaruh Ukuran PerusahaanTerhadap AggressiveTax avoidance Di Indonesia. Jurnal Akuntansi Multiparadigma Vol. 4 Hal. 165-329.

Sugiyono. 2010. Metode Penelitian Kuantitatif Kualitatif dan R\&D. Alfabeta. Bandung.

Suryana, Budi Anandita. 2013. Tax Evasion Pajak Properti. Diakses pada 25 Januari 2017 dari http://www.pajak.go.id/content/article/tax-evasion-pajak-properti.

Utami, M. W. 2013. Pengaruh Struktur Corporate Governance, Size, Profitabilitas Perusahaan Terhadap Tax Avoidance. Skripsi. Universitas Sebelas Maret. Surakarta. 